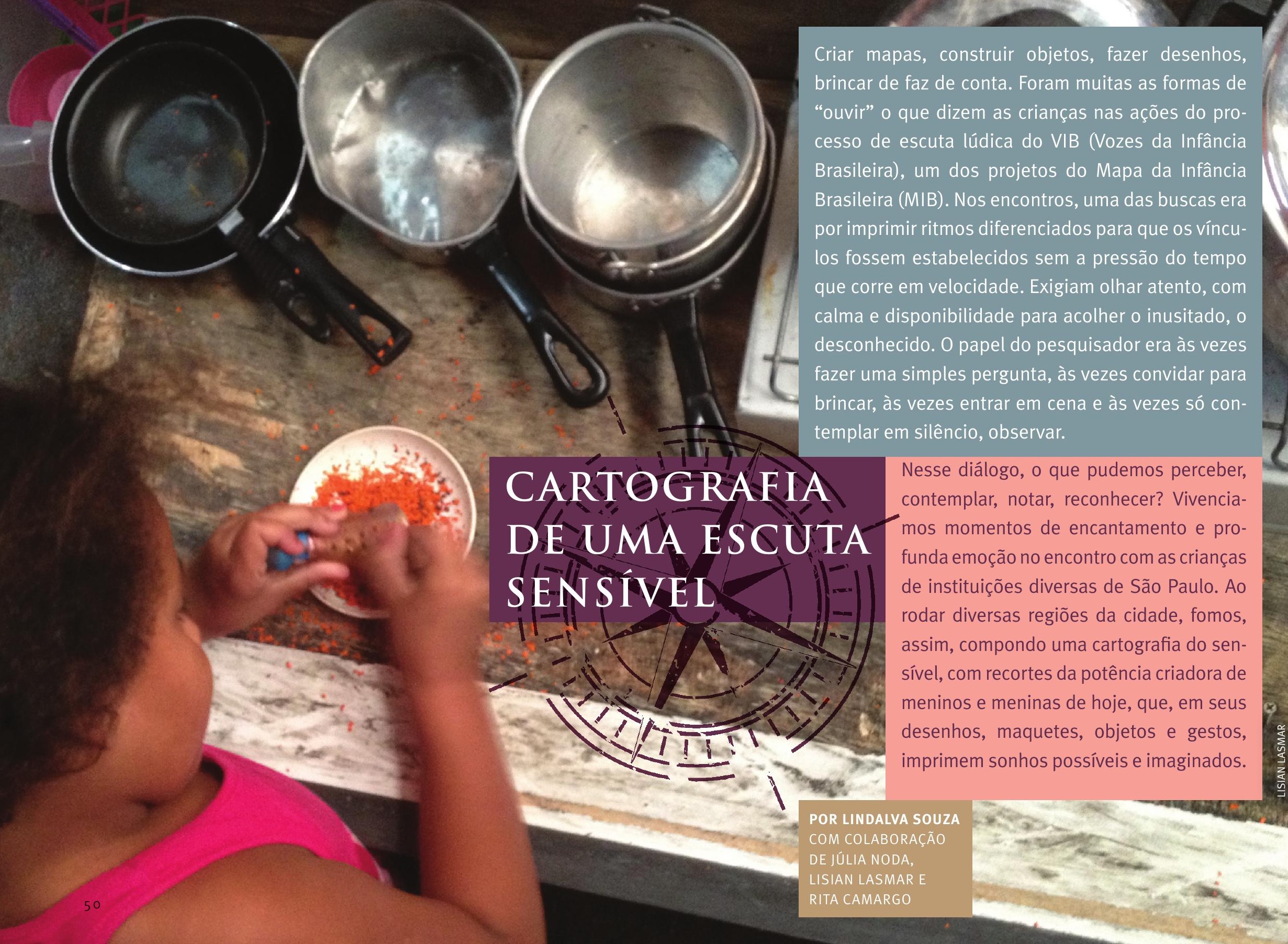




\section{O ENCONTRO}

Dois bebês, Rosa e Tom, cada um com cerca de sete meses, estavam próximos, brincavam a uma pequena distância no chão. Tom, que ainda não aprendera a rolar, moveu os braços e as pernas calmamente. Rosa rolava de um lado para o outro e se mostrava interessada em um pequeno objeto sonoro do lado oposto ao seu. 0 movimento e o som do instrumento chamaram a atenção da pequena. Ela fazia de tudo para pegá-lo. Tom movimentou as mãos lentamente, acariciou o tecido de chita que cobria o chão. Tanto encantamento naquelas cores carregadas de cultura popular. Sua investigação minuciosa na movimentação do tecido permitiu a descoberta de um pequeno fio. A descoberta seduziu a criança, que permaneceu maravilhada. Rosa e Tom estavam finalmente próximos, mas não se percebiam. Cada um deles se interessava por coisas diferentes. 0 movimento da Rosa de lá pra cá pra encontrar seu objeto lúdico permitiu que as suas costas se encostassem aos pezinhos de Tom. Rosa, que era puro resmungar, percebeu seu parceiro disponível para interação e cessou o choro. A proximidade do corpo do outro bebê que mantinha as pernas imóveis permitiu a Rosa fazer uma pausa. Ela se aconchegou o melhor que pôde nos pés do Tom. Tom percebeu e sorriu. Rosa se descobriu próxima, acarinhada naquele breve instante. Esse momento provocou em mim surpresa e admiração, pois o tempo ficou suspenso para registrar a magia e o encantamento do encontro entre os bebês Rosa e Tom, recém-chegados ao mundo.

\section{CELEBRAR A VIDA}

“Mama, oh!", expressou o pequeno Antônio, um ano de idade, e apontou para o bebedouro. A mãe atendeu ao pedido da criança, seguiu na direção indicada pelo filho, pegou um copo com água para ela e ofereceu outro ao pequeno. Antônio pegou o copo e exclamou: "Mama, bide!”, direcionando seu copo com água no copo da mãe. "Brinde!”, falou a mãe e a celebração se fez. "Ele adora brin-
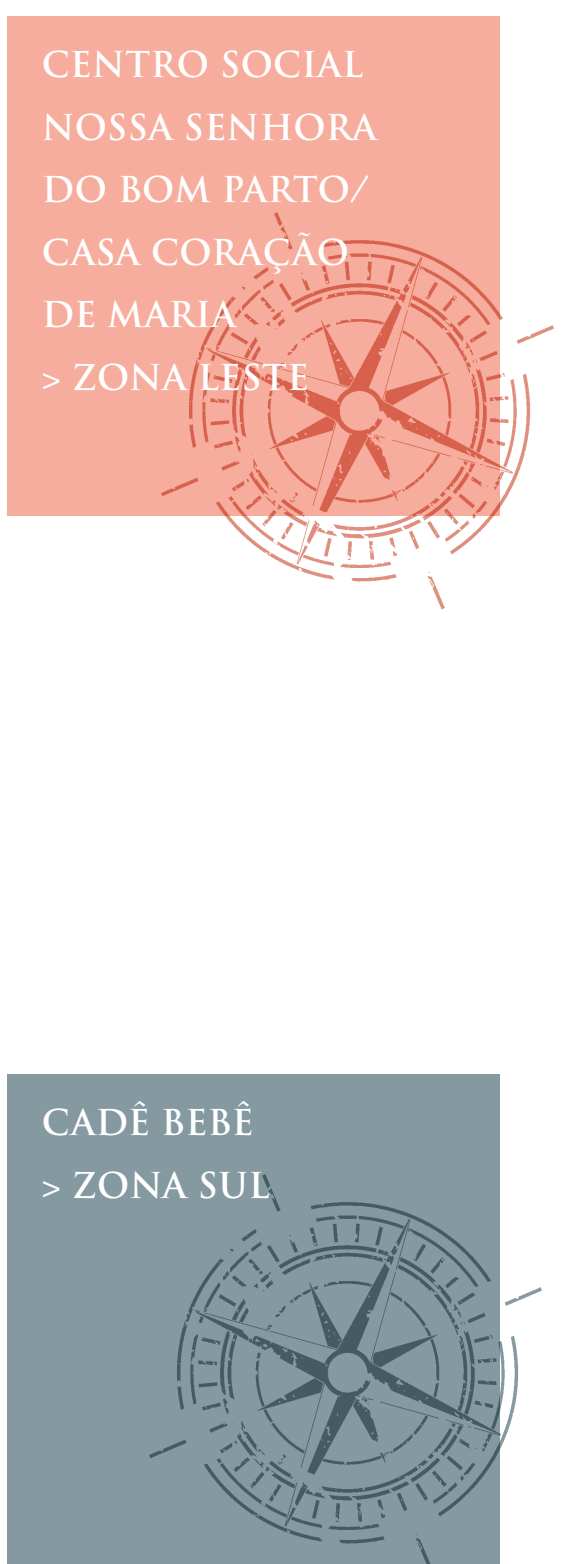
dar!”, comentou a mãe. A criança ficou eufórica, queria mais: “Mama, bide”. E os dois brindaram novamente. "Fazemos isso todo dia”, comentou a mãe. A euforia da criança para esse pequeno gesto me contagiou. Estava tão dentro da cena e tão sensibilizada com o momento que pedi para participar do brinde. 0 menino animou-se com o meu pedido e expressou mais uma vez sua frenética dança. Agora todo o corpo se movimentava em sinal de aprovação. A mãe também autorizou a minha participação naquela celebração e me entregou um copo com água. O pequeno demonstrou alegria e disparou largo sorriso. Nós três brindamos com entusiasmo e festejamos aquele breve instante. Sorvemos lentamente a água, um precioso líquido, em gesto de compromisso. Celebramos nosso pacto com a vida naquele momento e o tempo ficou suspenso... Aqui evidencio a transformação de quem observa e se vincula. Um momento que parece ser tão corriqueiro na vida das crianças e inesperado pra mim. Oportunidade para vivenciar e registrar pela primeira vez um breve instante de profundo respeito à celebração da vida.

\section{POR UM FIO}

O menino boliviano Davi tentava se comunicar em uma “língua” que eu não entendia. Não parecia ser espanhol. Quem sabe um dialeto boliviano ou outra língua da região? Tímido, ele não desgrudava de um elástico, que ora era guardado no bolso, ora era colocado sobre a mesa, o que deixava a criança concentrada. Fiz uma aproximação com um gesto: estiquei o elástico que o menino segurava e ele sorriu. Ele repetiu o movimento: esticou o elástico, colocou-o na mesa e depois guardou-o no bolso. Foi então que me lembrei das brincadeiras com barbante e da variedade de formas que poderiam surgir a partir das manobras criadas com as mãos. Cortei um pedaço do fio do barbante, amarrei as pontas e arranjei na mesa para ver a reação dele. 0 menino repetiu o gesto demonstrando interesse e houve correspondência na comunicação. Davi imediatamente se colocou em movimento para cortar e amarrar barbante. Ele demonstrou contentamento no gesto,

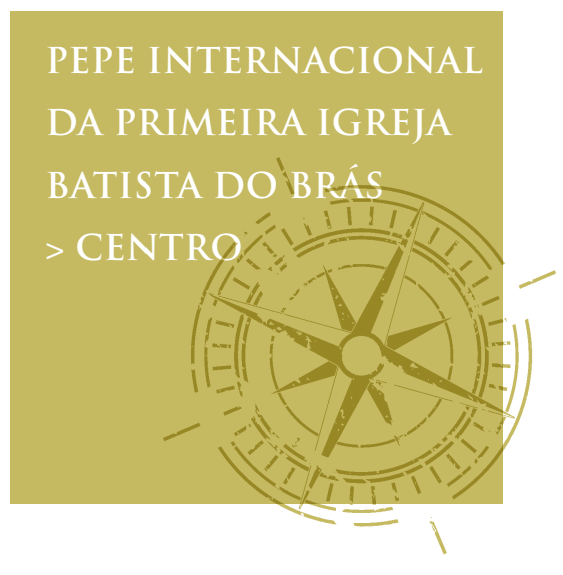




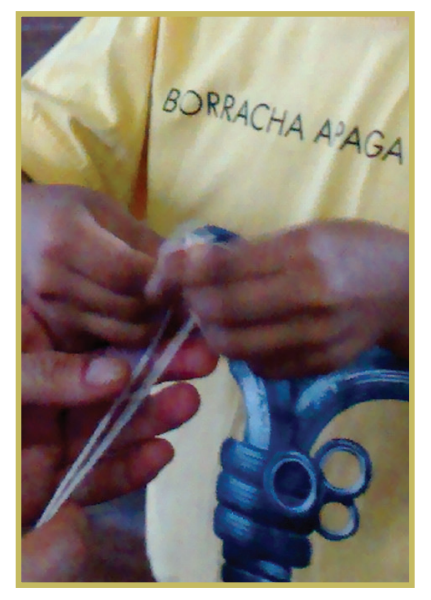

pegou o barbante amarrado e resolveu colocá-lo no pescoço de um bebê, filha de uma das educadoras. "Eliana, sua filha ganhou o primeiro colar”, disse Kátia. A fala da educadora animou o menino, que aproveitou e cortou outros pedaços de barbante para oferecer às outras educadoras. Fez questão de colocar ele mesmo “o colar” imaginário no pescoço de cada um dos adultos presentes. A empolgação de Davi chamou a atenção de Diana e Juliana, que também se interessaram pelo fio de algodão e interagiram com o menino. 0 maravilhamento por tantas descobertas permitiu ao Davi interagir com outras crianças que entraram na brincadeira e permaneceram concentradas no tempo de desenrolar e encompridar barbante.

\section{CORAÇÃO EMBRULHADO PRA PRESENTE}

“... Coração-bobo, coração-bola, coração-balão, coração-São-João. A gente se ilude, dizendo: já não há mais coração!”... Foi assim, cantarolando essa música de Alceu Valença, Coração Bobo, que saí depois de um encontro inspirador com Luig, um menino tímido de 9 anos que conheci no Espaço Alana, onde as crianças têm oportunidade para a livre expressão. Lá, numa atividade de desenhar, encontrei Luig insatisfeito com sua criação: um coração que não parecia perfeito. Ao gesto do menino de apagar o desenho, fiz uma observação: "Mas o seu desenho é tão diferente dos outros... Você viu os vários corações desenhados por outras crianças e os educadores?”. Ao observar os desenhos dos colegas, ficou pensativo... Aproveitou aquele tempo só dele para "dar forma" ao seu projeto. Resolveu, então, recriar as linhas da figura. No tempo dele, investigou cores, criou coragem e coloriu “seu coração" internamente. Esperou mais um tempo e separou outras cores de giz de cêra e canetinha. Mais uma pausa e arriscou o contorno... "Dar forma é formar-se:

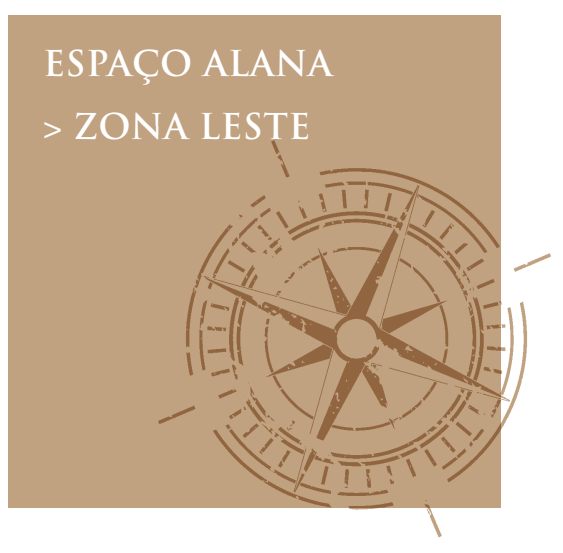




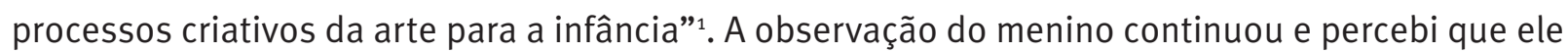
permaneceu mergulhado no tempo que inventou para finalizar a sua criação. Em gesto cuidadoso e impreciso, imprimiu com energia o desenho. Luig continuou no movimento do seu desenho e percebi que ele dobrava e embrulhava pra presente “o seu coração”. “É pra presente?”, perguntei. Ele fez um sim com a cabeça. "É pra minha mãe.” Delicadamente amarrou a fita colorida para finalizar o seu presente-criação.

1. Dissertação de Sirlene Gianotti sobre a expressão das crianças em ateliê de cerâmica.

\section{MENINOS EM TRAJETÓRIA}

Os meninos Pedro, Francisco e Nilo, amigos inseparáveis, demonstraram entusiasmo com o desafio de registrar no papel linhas e formas que desvendassem os caminhos percorridos pelo trio nas manhãs de domingo, no percurso entre suas casas e a igreja onde são realizadas as atividades do CAMI. Quais percepções eles teriam sobre o lugar onde vivem? Com um tempo prolongado, sem pressa, delinearam traços que traduziram os contornos das ruas, a forma das casas, o desenho dos prédios, o surgimento e o movimento das pessoas, a configuração do espaço público. Durante a atividade, as ações eram colaborativas. "Falta o carro, mas eu não sei desenhar”, disse Nilo. Francisco, o mais jovem, um menino ágil e atento, estava sempre disponível para ajudar. "Eu sei desenhar. Começa pela roda. Depois você faz as outras partes." "Falta a faixa de pedestre”, comentou Francisco. "Vou desenhar o farol”, arriscou Nilo, completando o desenho. Quando finalizaram a criação de suas imagens do lugar, o trio resolveu fixar os desenhos na parede. Observaram atentamente os desenhos e os detalhes no nome das ruas, a circulação dos carros, a localização dos vizinhos, a falta de áreas verdes, pois eram poucas as árvores. Perceberam que poderiam complementar e reorganizar a paisagem local. E, assim, integraram seus desenhos. Constataram que

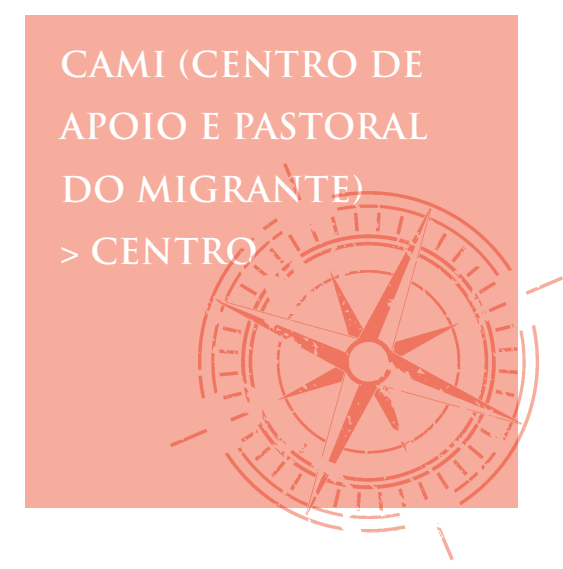


alguns caminhos se cruzavam. Resolveram, então, unir os desenhos individuais pelas ruas e criaram um mapa coletivo de imagens. Descobriam que era possível ampliar o papel e criar outras ruas, juntar casas, unir linhas e formas e histórias. Naquele momento, o encontro das ruas apresentavam o bairro inteiro. Passaram então a refletir sobre o que as crianças sentiam falta naquele trajeto, quais suas observações, o que havia de bonito e de feio. "Se a gente virar aqui, dá na outra rua e depois na outra." Fiquei impressionada com as descobertas e as sugestões para a melhoria do trajeto entre a casa e a igreja feitas pelas crianças.

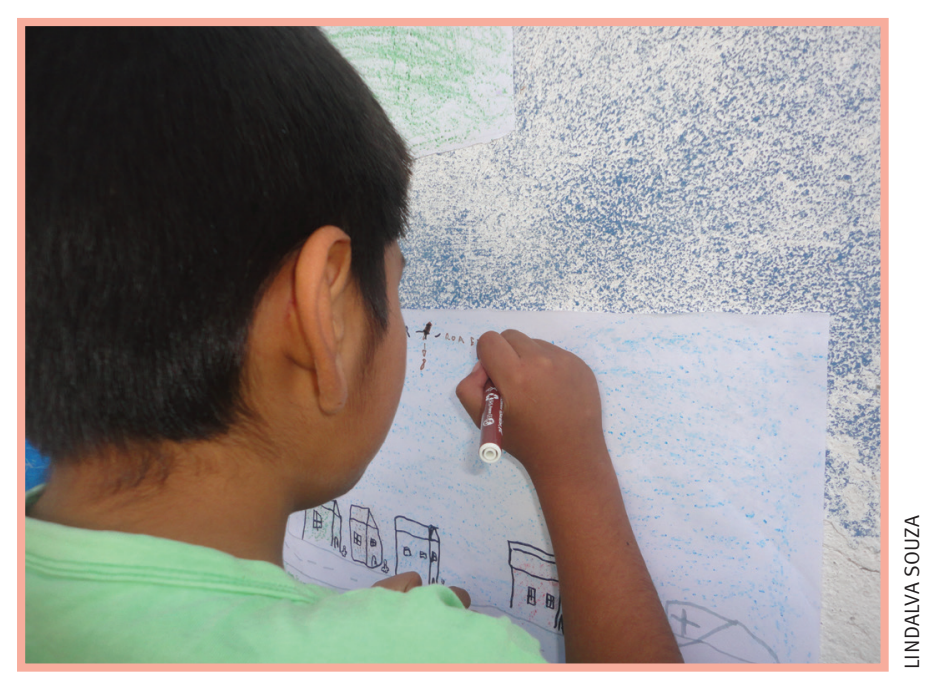

\section{POESIA CONCRETA}

O espaço do Sacolão das Artes era transformado semanalmente em um inusitado restaurante por um grupo de crianças. Elas organizavam mesa, cadeiras e utensílios domésticos como panelas, tampas, copos e talheres criando um ambiente diferenciado no lugar. As meninas representavam e se revezavam nos papéis de cozinheira, garçonete, gerente e cliente do restaurante. "É muito legal essa brincadeira!”, repetiam em coro. Alguns meninos e as pesquisadoras foram, então, convidados a participar do jogo inventado pelas garotas. A garçonete, sempre gentil, dizia aos clientes que ficassem à vontade e informava as opções disponíveis no cardápio: "Inhoque colorido, suco natural de laranja e salada verde". "Sobremesa? Pudim.” A animação era total na brincadeira e a manipulação dos utensílios e a preparação dos pratos eram minuciosas. "O que mais tem pra comer?", perguntou um cliente. "Tem de tudo, é só pedir." Na interação, perguntamos como poderíamos pagar aque-

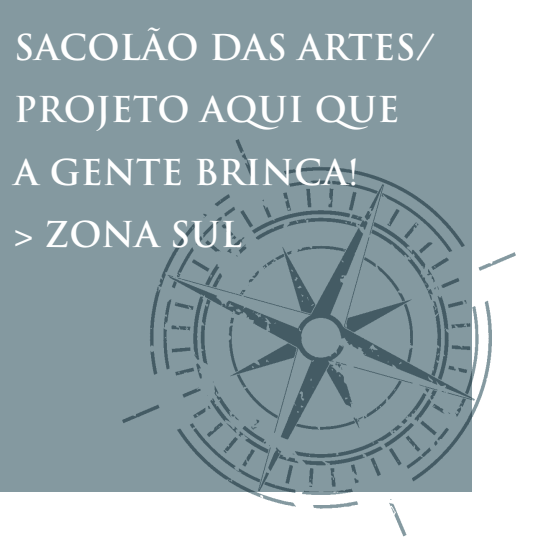
le "alimento" que nutriu nossa alma. Elas ficaram pensativas. Resolvemos, então, improvisar com papel e caneta nossos cartões de crédito e as notas para pagar a conta. Esse movimento estimulou outras crianças, que também criaram seu próprio dinheiro para quitar o débito no restaurante 
imaginário. "Você só me deu $\mathrm{R} \$$ 5,00. A conta é de $\mathrm{R} \$$ 20,00." Imediatamente, uma das meninas que reconheceu o cartão de crédito desenhado no papel, inventou uma máquina para passar o cartão de pagamento, com lápis e papel. Emocionou o desenvolvimento do enredo de forma espontânea, viva e dinâmica. Tudo era transformado com relação às demandas que surgiam naquele momento. Foi possível observar vivências significativas e desafiadoras na rapidez das respostas, na agilidade do pensamento e ação dos participantes na delimitação do espaço para a ação do jogo.

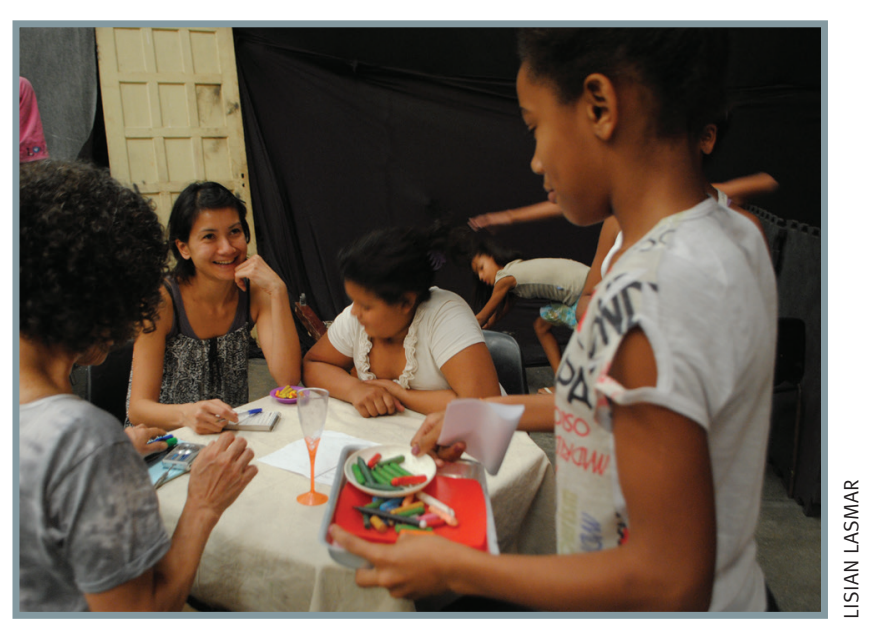

\section{A POESIA DE CADA DIA}

Tayná, sete anos, é uma menina franzina e tímida, construtora de sonhos. Na roda de apresentação, entre muitas crianças, não conseguiu falar por conta da extrema timidez. Os amigos logo avisaram: "Ela não gosta de falar!". Emergiu o sentimento de quem observa em silêncio: eu também sempre fui bem tímida e me dava enorme frio na barriga quando tinha que me apresentar. Mais tarde, ao finalizar a atividade de desenho, ela por acaso ficou ao meu lado. Tayná se dedicava a construir um pequeno objeto em dobradura com alguns papéis que estavam por ali. Dobrava aqui, virava, dobrava ali cuidadosamente. Para finalizar, criou pequenos desenhos coloridos em forma de coração. De todo esse movimento surgiu uma máquina de tirar fotos em dobradura de papel! Conversei com ela para saber como se fazia aquele brinquedo e, para minha surpresa, ela falava normalmente. Tinha fala baixa, mansa, tranquila, mas conversava e me explicava entusiasmada como fazia a tal máquina para tirar fotos. Máquina na mão, ela se colocou em posição para fotografar uma amiga que estava próxima. Outras crianças também entraram na brincadeira. Ela aproveitou o meu interesse e tirou uma foto minha com sua máquina de papel. Eu tirei fotos dela em ação com a minha máquina de verdade. Depois, revendo a imagem, percebi a delicadeza dos

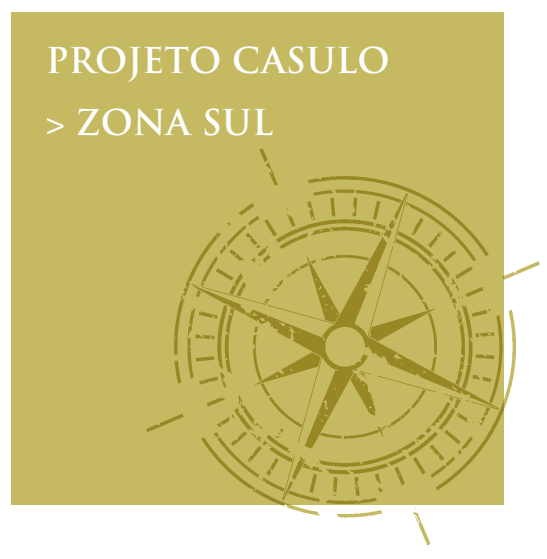


seus gestos em capturar as fotos e olhar pelo orifício da máquina fotográfica inventada. Pensei: será que foi porque eu estava ali tirando fotos que ela também quis fazer uma câmera fotográfica? Será que gostaria de ver através da lente da sua câmara o que os meus olhos viam quando eu fazia o registro das expressões das crianças na sala? Criar diálogos, estabelecer vínculos e observar silenciosamente permitiu o registro da história da Tayná, que nos deixa pistas para que tenhamos coragem de reconhecer o potencial poético expressivo que pode surgir quando nos dispomos a encontrar pistas para expressar o que sentimos.

\section{A SEMENTE}

Uma história em especial chamou minha atenção naquele dia. Clara, uma menina de 4 anos, desenhava uma árvore. Os traços no papel indicavam que ela tinha experiência e intimidade com a linguagem. Deixou o seu desenho de lado e saiu na direção de outras crianças. Depois de um tempo, ela voltou para onde havia deixado o seu desenho e registrou outra imagem de uma árvore. Fiquei

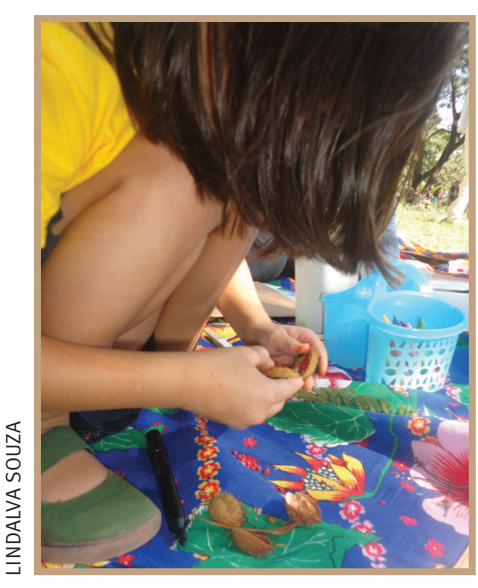

curiosa e perguntei que árvore era aquela. A menina apontou para uma pequena árvore que estava próxima. Caminhei na direção da árvore para ver o que havia de especial naquela planta. Cheguei perto e qual não foi a minha surpresa: era um pé de urucum carregado de frutos secos que, ao serem abertos, revelaram sementes avermelhadas. "Clara, você conhece esta árvore?”, perguntei. Ela disse que não. “É uma árvore de urucum.” "O que é urucum?”, perguntou a menina. “É uma árvore que dá sementes coloridas.” Ela ficou curiosa e então colhemos alguns frutos para observar as sementes. Clara ficou surpresa com a cor das pequenas sementes. "Podemos desenhar com elas. Vamos testar?”, convidei. Ela ficou interessada no experimento. Molhamos as sementes em um copo com água e a menina descobriu que a
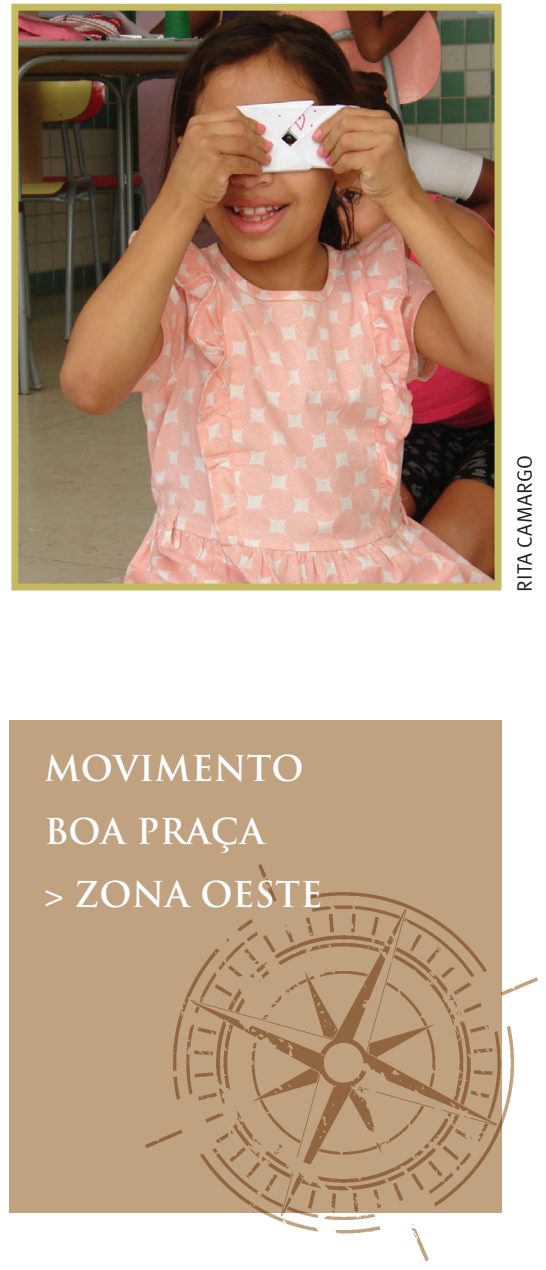
cor avermelhada ficava potencializada no contato com o líquido. Sugeri que ela ensaiasse rabiscar no papel e na pele. Entre conversa e experimentação, Clara imprimiu formas no papel, no seu próprio corpo e nas mãozinhas da sua irmã. A expressão singular da menina aproximou gerações, formou novos vínculos, construiu confiança, produziu uma história significativa.

\section{INSTITUIÇÕES}

\section{CENTRO SOCIAL NOSSA SENHORA DO BOM PARTO/} CASA CORAÇÃO DE MARIA

Entidade filantrópica, ligada à Pastoral do Menor. Foi fundada em 1946, quando um grupo de senhoras católicas decidiram desenvolver ações de assistência a jovens da região.

\section{CADÊ BEBÊ}

O projeto foi criado para que os pequenos e seus acompanhantes desfrutem de um espaço para criar, explorar e brincar ao longo dos primeiros anos de vida. Atende crianças até 3 anos acompanhadas dos pais ou adultos responsáveis.

\section{PEPE INTERNACIONAL}

É um programa socioeducativo promovido por Missões Mundiais. Oferece às crianças a oportunidade de obter um preparo educacional que estimule seu desenvolvimento integral.

\section{ESPAÇO ALANA}

Criado há 20 anos no Jardim Pantanal, bairro de extrema vulnerabilidade na zona leste, fomenta o desenvolvimento local por meio de ações socioeducativas e de articulação comunitária. Atende crianças até 12 anos.

\section{CAMI}

(CENTRO DE APOIO E PASTORAL DO MIGRANTE)

Desenvolve trabalhos em comunidades com grande número de migrantes, em parceria com igrejas e outras instituições. Também atua na discussão e na proposição de políticas migratórias.

\section{SACOLÃO DAS ARTES / PROJETO AQUI QUE A GENTE BRINCA!}

Um trabalho de construção coletiva, criado

para atender crianças, jovens e educadores e ser

espaço de referência da cultura lúdica, no

Parque Santo Antônio, região sul da cidade de São Paulo.

\section{PROJETO CASULO}

Oferece atividades socioeducativas, culturais e de interação comunitária no contraturno escolar. Atua com crianças, jovens e famílias das comunidades do Real Parque do Morumbi e Jardim Panorama.

\section{MOVIMENTO BOA PRAÇA}

Iniciativa com a intenção de mobilizar cidadãos e vizinhança para ocupar e revitalizar os espaços públicos, em especial as praças da cidade. Realizam diversas ações, como hortas e piqueniques comunitários.

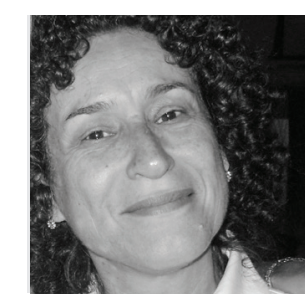

\section{LINDALVA SOUZA}

Arte-educadora e pesquisadora da área da infância, com larga experiência em formação continuada para professores e programas socioeducativos e culturais para crianças. Coordena o Vozes da Infância Brasileira, o VIB, um processo de escuta lúdica, um dos projetos da comunidade colaborativa de aprendizagem Mapa da Infância Brasileira - MIB (www.mapadainfanciabrasileira. com.br), que reúne instituições, fundações, redes, órgãos públicos, ONGs e coletivos que impactam na qualidade de vida de crianças, assim como suas famílias e comunidades. 
Vivendo em palafitas sobre o rio Itaya, na selva peruana, a comunidade de Belén, em Iquitos, estava condenada a desaparecer, vítima de doenças e do descaso do setor público. Mas o curso da história desse rio foi alterado com a chegada da organização Infant Perú.

Em Iquitos, o instituto também desenvolveu uma metodologia que prioriza a escuta das crianças para promover a infância como parte integrante de uma sociedade. Com o método participativo da organização, há rodas de conversas e oficinas de desenhos e fotografias em que as crianças contam como é ser criança, quais são os pontos fortes e fracos e quais propostas apresentam para os locais onde moram.

0 resultado dessa metodologia fez nascer meninos e meninas empoderados em Iquitos. Lá, eles desenvolvem diversos tipos de campanhas como exercício de sua cidadania. Hoje, as crianças de Belén são as guardiãs da água e querem transformar seu amado rio Itaya em um porto ecológico da ternura.

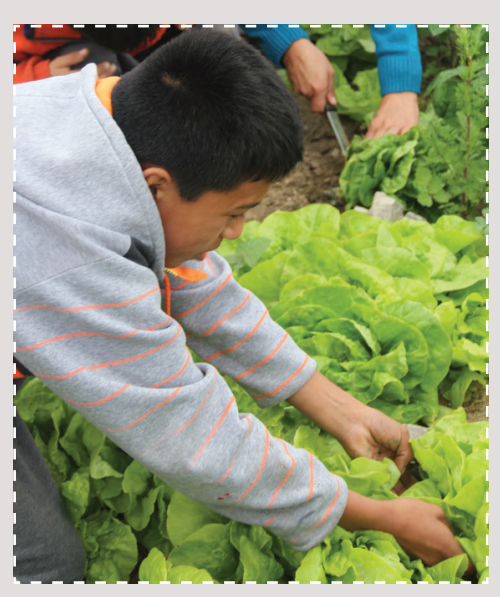

Na seca, o rio encolhe e deixa aparente montanhas de lixo em suas margens. Mas um batalhão de crianças, munidas de luvas e máscaras, passam por lá para recolher a sujeira, transformando o lixo em brinquedos e outros tipos de reciclagem.

$\mathrm{Na}$ época das chuvas, o rio sobe quatro metros, alcançando as varandas das palafitas. Por muito tempo bebês eram levados pela fúria das águas. Mas, com o projeto Niños al Rescate, as crianças viraram salva-vidas. Capacitadas pelo corpo de bombeiros, elas patrulham o rio e ajudam nos primeiros socorros de crianças pequenas, com menos de cinco anos, que não sabem nadar. Elas também foram protagonistas na aprovação de uma Encontro com as infâncias O Infant Perú, que surgiu em 1999, também atua em outras 17 localidades do país. Belén é um exemplo dessa iniciativa bem-sucedida. Em outubro de 2016 organizaram no Peru o Encontro Internacional das Infâncias - Com Ternura, um Outro Mundo é Possível. Vale acompanhar o site da instituição. www.infant.org.pe lei, sancionada em 2015, que proíbe castigos e violência contra a infância. 
No primeiro episódio da série Te Re-Creo, a telinha mostra três pequenos âncoras que se revezam para apresentar uma enquete que indaga de alunos de escolas colombianas como deveria ser um noticiário infantil.

Logo pipocam reportagens com depoimentos de crianças que Gabi, uma das apresentadoras do programa, se apressa em anotar. "Notícia só para crianças", diz um dos meninos. Outras respondem: "O programa precisa ter o que as crianças necessitam, querem e sentem" e "é preciso mostrar o que se passa nos colégios". Finalmente, uma garotinha arremata: "Notícias de crianças não podem acontecer com pessoas grandes porque elas não têm a mesma imaginação que nós temos".

Foi com essa pauta que todo o conteúdo da série foi consolidado. O programa, pioneiro na Colômbia, é fruto de uma co-produção entre a Secretaria de Educação e a emissora de TV Canal Capital, ambas do governo de Bogotá. A série surgiu em 2013 e em 2014 faturou o prêmio Unicef no Prix Jeunesse Internacional, onde concorreram 90 produções do mundo.

Com cerca de 23 minutos cada um, os episódios mostram crianças como guias de noticiários nas escolas. Temas como jogos, relação entre alunos e professores, culinária e curiosidades são abordados de um jeito que emociona e diverte. Mais do que promover notícias, o programa busca a produção de narrativas do ponto de vista da criança como cidadã.

Mónica Baquero, diretora da série, conta que a produção aconteceu de forma semelhante a qualquer outro programa de TV, que tem pesquisa e pré-produção, mas que sua equipe de profissionais precisou estar atenta para motivar e transmitir confiança às crianças. E, para garantir que os 34 episódios tivessem apenas as perspectivas e o coração das crianças, a produção trabalhou para que os colégios fossem sempre seus aliados em uma luta que objetivou o empoderamento da infância.

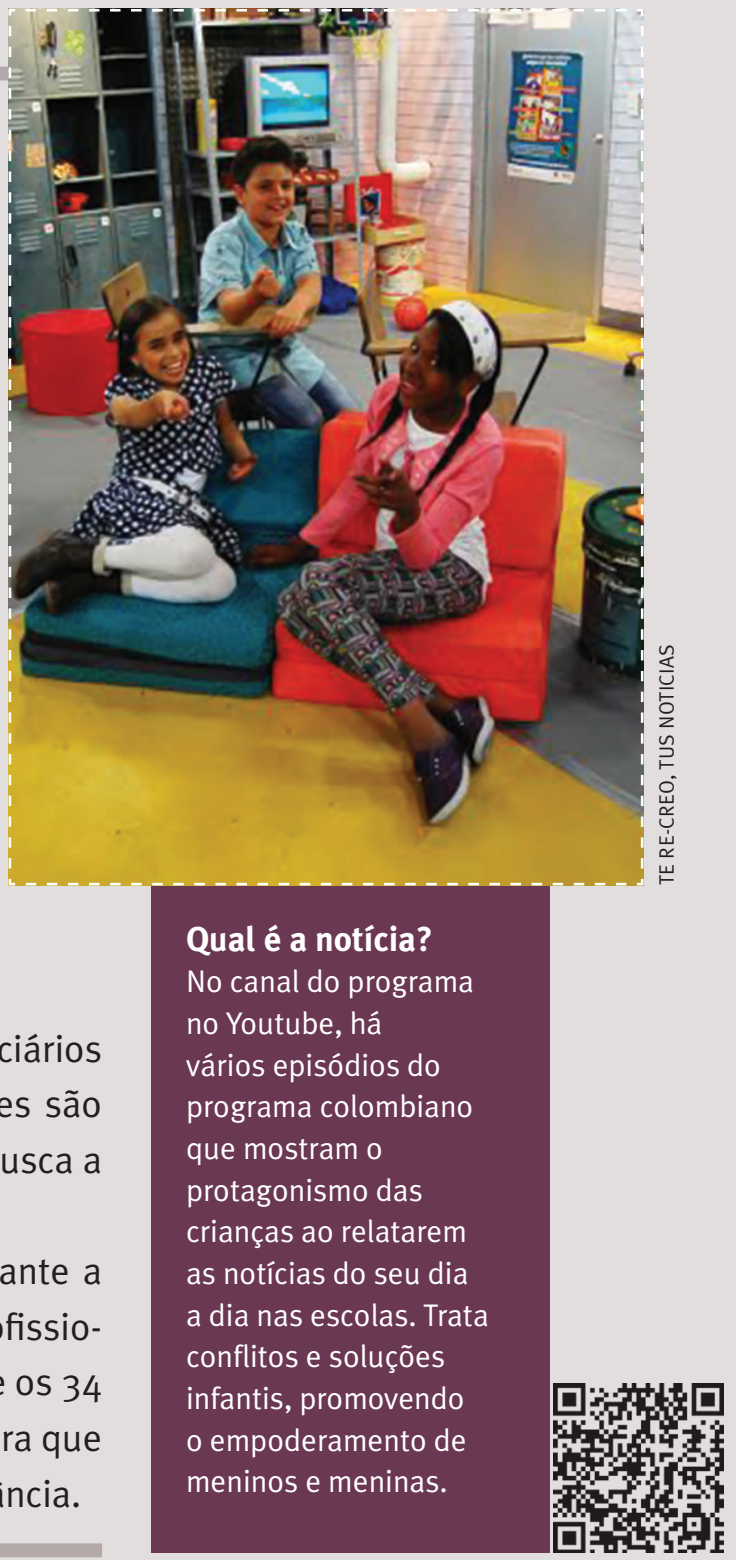

